\title{
A Message from the National Consortium for Building Healthy Academic Communities President Resiliency: A Key Protective Factor in Challenging Times
}

We now have a mental health pandemic occurring within the COVID-19 pandemic. In the latest Morbidity and Mortality Weekly Report by the Centers for Disease Control and Prevention, findings from a recent survey indicated that one out of four 18 to 24 -year-olds report having suicidal ideations since the pandemic started. Research also has shown that one out of three Americans now have clinical anxiety and depression. There is no doubt that people and institutions with higher levels of resiliency will weather the COVID-19 storm more successfully than those who lack this protective factor. A large misperception exists about resilience, that is, we are out of luck if we are not born with it. However, that could not be further from the truth. Resiliency can be built and strengthened over the course of one's life and we must do all that we can to equip our faculty, staff, and students with the skills needed to become more resilient. As one example, the practice of daily gratitude is one of these resiliency skills that has been shown through research to improve optimism, mood, and sleep as well as decrease blood pressure. We feature this resiliency skill in our return to campus guide, which is filled with other awesome tips and strategies on enhancing student health and wellness. Spread news of this guide widely at https://healthyacademics.org/campusguide. Please also check out the latest report on the state of resiliency in America at https://www.everydayhealth.com/wellness/state-of-resilience/. At this website, you can assess your own resiliency with a valid and reliable tool and gain key tips for building it. We cannot wait for any further crises or pandemics to place emphasis on and invest in more resources to build resiliency in our academic communities, which is why the theme for our upcoming virtual national summit in April will focus on resilience.

We have just created an exciting new five-year strategic plan for our terrific organization, which will be sent to our membership shortly and highlighted on our Building Healthy Academic Communities (BHAC) website soon. I would like to thank Kat Marriott and our board of directors for their terrific efforts and energy in formulating the roadmap for the next phase of our important journey together, including Megan Amaya, Stacy Connell, Mary Johnson, Lindsey Nanny, Mario Ortiz, and Brenda Seals. I am most grateful to our outgoing board members, including Stacy Connell, Mary Johnson, Mario Ortiz, and Brenda Seals for the outstanding service they have provided to our organization. The slate for our next board of directors open positions will be launched shortly. I am eager to welcome new board members and continue to provide leadership for our dynamic impactful organization.

I also would like to thank Meredith Kazer who has done a terrific job in her role as our inaugural editor for our BHAC journal. We have just reached an important milestone of 50 published papers, which is a key number for applying to have our journal indexed. Please continue to share news about our awesome journal and submit your wonderful work for publication consideration.

As we continue our journey together, remember that you cannot be fully engaged in your roles and take good care of others unless you take good self-care. Build in short recovery breaks during your days to engage in physical activity, gratitude practices, or mindfulness so that you stay healthy and strong as you cannot pour from an empty cup. Best wishes and stay well!

Fond regards,

Bernadette Mazurek Melnyk, PhD, APRN-CNP, FNAP, FAAN 
President and Founder, the National Consortium for BHAC

Vice President for Health Promotion

\section{University Chief Wellness Officer}

Dean and Helene Fuld Health Trust Professor of Evidence-based Practice, College of Nursing

Professor of Pediatrics and Psychiatry, College of Medicine

Executive Director, the Helene Fuld Health Trust National Institute for Evidence-based Practice

The Ohio State University 